established in 1955 by the World Meteorological Organization in honour of the former non-Governmental Organization which had initiated international collaboration in moteorology in 1878, but which ceased in 1951 when the World Meteorological Organization took over.

\section{Pure Mathematics at Birmingham :}

Prof. P. J. Hilton

Prof. P. J. Huton is vacating tho Mason chair of pure mathematics in the University of Birmingham on being appointed to a professorship in pure mathematics in Cornell University. Prof. Hilton, who is thirty-nine years of age, was educated at St. Paul's School and Queen's College, Oxford, obtaining a firstclass degree in mathematics while at the latter. After the War he returned to Oxford to work in algebraic topology under the late Prof. J. H. C. Whitehead and was one of the leading members of the brilliant band of topologists taught by Prof. Whitehead. After obtaining the Ph.D. degree ho went to Manchester in 1948, where he remained until 1952. He then spent three years in Cambridge as lecturer and returned to Manchester in 1955 , where he remained until 1958, when ho was appointed to the Mason chair at Birmingham. Prof. Hilton has made outstanding contributions to algobraic topology, particularly in the field of homotopy. In recent years he has worked in close collaboration with Prof. Eckmann of Zurich, and their joint work is among the most interesting and important contributions being made to topology at the present time. In addition, Prof. Hilton has written a tract on homotopy theory and also, in collaboration with S. Wylie, a book on homology theory. Both are clear expositions of algebraic topology.

Prof. A. M. Macbeath

Prof. A. M. Macheath, who has been appointed to succeed Prof. Hilton, is thirty-nine years of age. $\mathrm{He}$ was educated at the Royal Belfast Academic Institution, The Queen's University of Belfast, where he obtained a first-class degree in mathematies, and Clare College, Cambridge. After obtaining first. class honours in the Mathematical Tripos, he commenced research in the geometry of numbers under Prof. L. J. Mordell. For his research in this subject he was awarded a Sinith's Prize. From 1948 until 1950 he was at Princeton University with a Commonwealth Fellowship, whore he obtained a Ph.D. degree. From this period dates his interest in measure theory and topological groups, in which fields he has carried out research in more recent times. After his return to England, he went to the University of North Staffordshire from 1951 until 1953 as a lecturer, and was then appointed to the chair of mathematics in University College, Dundee (University of St. Andrews), whore he has remained until the present time. As already indicated, Prof. Macbeath's field of research has widened from his original interest in the geometry of numbers to embrace both moasure theory and, more latterly, discontinuous groups. While at Dundee he has written a steady stream of papers on these subjects.

Applied Physics at Hull :

Prof. J. Ring

Dr. JAMme Ring, who has been appointed to the new chair of applied physics in the University of Hull, was an undergraduate and research student in the University of Manchester. He later became lec. turer, senior lecturer and reader in spectroscopy there.
His first postgraduate work was on the improvement of spectroscopic techniques by applying the then new multiple dielectric layers to the Fabry-Perot interferometer. Dr. King has continued to play a prominent part in the modern revival of experimental spectroscopy which has resulted largely from recognition of the special qualities and the special optical requirements of such detectors as photomultipliers and infra-red sensitive cells. He has contributed especially by developing pressure-scanned interferometers and by applying them to astronomical and other purposes. He has also worked on the closely related interferonce filters, dealing with their production, the extension of their spectral range, and their application: astronomy has again received his special interest. In 1960 it was recognized by the Departiment of Scientific and Industrial Research that Ir. Ring's work, devoted to techniques used over a wide scientific fiold, occupied a special position, and he was made director of a specially financed project in which a team of research students and more senior assistants, with technical support, developed instruments and methods for use by chemists and astronomers as well as physicists. This team has worked successfully for a year or so and it is hoped that a considerable part of it will be trans ferred to Hull.

\section{Computer Network for Australia}

THe Australian Federal Cabinet has agreed to the establishmont by the Commonwealth Scientific and Industrial Research Organization of a system of electronic computers for their own use, universities and Cornmonwenlth Government departments and authorities. It is hoped that the first stage of the project, which will cost nore than $£ 1,500,000$, will come into operation in about eighteen months time. The central unit of tho system will be a large and powerful computer, located in Canborra. The Government is to set aside $£ 100,000$ for a laboratory to house it. 'Satellite' computers will be set up in Sydney, Melbourne, Canberra and Adelaide. All the units will be programmed in the same way and will make up an integrated network. About forty people, including twelve scientistis, will be appointed to the project. C.S.I.R.O. will be the biggest single user of the network. Several other Government departments and agoncies, including the Atomic Energy Commission, the Burcau of Meteorology, the Post-Master General's Department and the Aeronautical Research Laboratories, will make extensive use of the computers. In the future, the Atomic Energy Commission and some departments and universities will acquire their own 'satellite' computers which they will operate thomselves as part of the system. It is estimated that by 1965 C.S.I.R.O. alone will need at least 5,000 hr. of 'satellite' computer time in a year, plus $1,500 \mathrm{hr}$. on the central unit. Other Government users will together need more than that. At the present time, Australia's computing needs are doubling every year.

\section{The Commonwealth Agricultural Bureaux}

IN reply to a question in the House of Lords on May 28, the Parliamentary Under-Secretary of State for Commonwealth Relations, the Duke of Devonshire, said that the Government had no reason to believe that the Commonwealth Agricultural Bureaux were unlikely to be able to continue successfully under existing arrangements for scientific co-operation in the Commonwealth. These arrangements for scientific 